\title{
PENENTUAN KAPASITAS ANTIOKSIDAN DAN KANDUNGAN FENOLIK TOTAL EKSTRAK KASAR TERIPANG PASIR (Holothuriascabra) DARI PANTAI KENJERAN SURABAYA
}

\author{
Juliyantoro Ali Wafa, Tri Kustono Adi, Ahmad Hanapi, A. Ghanaim Fasya \\ Jurusan Kimia, Fakultas Saind dan Teknologi, UIN Maulana Malik Ibrahim Malang
}

\begin{abstract}
The antioxidant capacity and total phenolic compounds content of sea cucumber (Holothuriascabra)crude extractfrom Kenjeran, Surabaya was analysed. The crude extract was obtained by maceration-partition using methanol and $n$-hexane. The total antioxidant capacity of both methanol and $n$-hexane crude extract was estimated by DPPH assay while the total phenolic was measured by Folin-Ciocalteauassay. Phytochemical reagent assay and Thin Layer Chromatography (TLC) were also applied for early identification and separation of the unknown compound of both extract.

The result showed that the methanol and $n$-hexane extracts have antioxidant capacity of $78.92 \%$ and $94.82 \%$. Total phenolic content of methanol and $n$-hexane extracts were obtained as $69.09 \mathrm{mg}$ GAE/g and 58.01 $\mathrm{mg}$ GAE/g. Early identification of the crude extracts showed the presence of triterpenoid group in methanol extract and saponin group in $n$-hexane extract. The TLC on the methanol extraxt using $n$-butanol: $\mathrm{NH}_{4} \mathrm{OH}(4: 1)$ generated four spots.
\end{abstract}

Keywords: Holuthuriascabra, DPPH, Total Phenolics, Antioxidant, TLC

\section{ABSTRAK}

Kapasitas antioksidan dan fenolik total ekstrak teripang pasir (Holothuriascabra) dari Pantai Kenjeran, Surabaya telah dianalisis. Ekstrak kasar diperoleh dengan maserasi-partisi menggunakan metanol dan $n$-heksana. Penentuan kapasitas antioksidan dari kedua ekstrak kasar metanol dan $n$-heksana dilakukan menggunakan uji DPPH, sedangkan fenolik total menggunakan metode Folin-Ciocalteau. Uji reagen dan Kromatografi Lapisan Tipis (KLT) juga dilakukan untuk identifikasi awal dan pemisahan senyawa yang tidak diketahui dari ekstrak keduanya.

Hasil penelitian menunjukkan bahwa ekstrak metanol dan $n$-heksana memiliki kapasitas antioksidan $78,92 \%$ dan $94,82 \%$. Fenolik total ekstrak metanol dan n-heksan yang diperoleh sebesar 69,09 mg EAG/g sampel dan $58.01 \mathrm{mg}$ EAG/g sampel. Identifikasi awal dari ekstrak kasar menunjukkan adanya senyawa triterpenoid pada ekstrak metanol dan senyawa saponin pada ekstrak $n$-heksana. KLT pada ekstrak metanol menggunakan $n$-butanol: $\mathrm{NH}_{4} \mathrm{OH}(4: 1)$ diperoleh empat spot.

Kata Kunci:Holothuria scabra, DPPH, Fenolik Total, Antioksidan, KLT

\section{PENDAHULUAN}

Laut Indonesia terdiri atas 3,2 juta $\mathrm{km}^{2}$ laut teritorial dan 2,9 juta $\mathrm{km}^{2}$ perairan ZEE (Zona Ekonomi Eksklusif). Wilayah perairan 6,1 juta $\mathrm{km}^{2}$ tersebut adalah $77 \%$ dari seluruh luas Indonesia (Pokja, Kadin, \& Batam, 2004). Laut mampu meningkatkan keunggulan komparatif bangsa dilihat dari segi luas dan keanekaragaman hayatinya. Salah satu biota laut yang berpotensi menghasilkan senyawa bioaktif yang dapat digunakan sebagai bahan baku obat-obatan adalah teripang pasir. Matranga (2005) menyatakan bahwa teripang pasir sudah ratusan tahun digunakan sebagai obatobatan di Cina dan diyakini mampu menyembuhkan berbagai jenis penyakit.

Teripang pasir dapat ditemukan hampir di seluruh perairan pantai, mulai daerah pasang surut yang dangkal sampai perairan yang lebih dalam. Menurut Sateni (2012), teripang pasir hidup di dasar substrat pasir, lumpur pasiran, atau dalam lingkungan terumbu, dengan pergerakan yang lambat. Di pantai Kenjeran Surabaya, teripang pasir sering diolah menjadi makanan kerupuk. Harga teripang pasir 
sendiri setelah diolah menjadi kerupuk sekitar Rp.150.000,-/kg dibandingkan harga sebelum diolah yaitu sekitar Rp.5.000,-/kg. Oleh karena itu, masyarakat Kenjeran Surabaya lebih suka menjual teripang pasir dalam bentuk kerupuk teripang pasir. Nurhidayati (2009),Teripang pasir (Holothuria scabra) diduga mengandung senyawa yang bersifat antioksidan yaitu vitamin $\mathrm{A}, \mathrm{C}$, dan $\mathrm{E}$, senyawa flavonoid dan polifenol, DHA, EPA, dan kondroitin sulfat. Senyawasenyawa ini sangat potensial dalam meredam radikal bebas dalam tubuh. Selain itu, teripang pasir juga diduga senyawa antiinflamasi yaitu DHA dan EPA, dan kondroitin sulfat, sehingga bila telah terjadi kerusakan sel akibat radikal bebas, kerusakan yang lebih parah dapat dihindari.

Tujuan dari penelitian ini adalah untuk mengetahui kandungan senyawa fenolik dan kapasitas antioksidan ekstrak teripang pasir dari pantai Kenjeran Surabaya, yang diekstrak dengan dua jenis pelarut, yaitu metanol dan $n$-heksana hasil destilasi. Hasil dari penelitian ini nantinya diaplikasikan sebagai sumber senyawa antioksidan.

\section{METODE PENELITIAN Bahan}

Bahan yang digunakan dalam penelitian ini adalah teripang pasir (Holothuriascabra) yang diperoleh dari pantai Kenjeran Surabaya.

\section{Analisis Kadar Air}

Analisis kadar air dilakukan pada bagian tubuh teripang pasir. Sebelumnya cawan dipanaskan dalam oven pada suhu $100-105^{\circ} \mathrm{C}$ selama 15 menit untuk menghilangkan kadar airnya, kemudian cawan disimpan dalam vacumdesikator sekitar 10 menit. Cawan tersebut selanjutnya ditimbang dan dilakukan perlakuan yang sama sampai diperoleh berat cawan yang konstan. Sampel teripang pasirbasah dimasukkan ke dalam cawan yang telah diketahui berat konstannya. Sampel yang sudah dipotong kecil-kecil diambil 5 gram dan dikeringkan ke dalam oven pada suhu $100-105^{\circ} \mathrm{C}$ selama 15 menit untuk menghilangkan kadar air dalam tubuh teripang pasir, kemudian sampel disimpan dalam vacumdesikator selama 10 menit dan ditimbang. Sampel tersebut dipanaskan kembali dalam oven 15 menit, didinginkan dalam vacumdesikator dan ditimbang kembali. Perlakuan ini diulangi sampai berat konstan.

\section{Uji Kadar Garam}

Teripang pasir basahditimbang sebanyak 10 gram. Diekstrak menggunakan aquades panas $100 \mathrm{~mL}$, didiamkan selama \pm 1 menit, kemudian disaring dengan kertas saring. Hasil yang diperoleh diteteskan pada prisma pembaca pada salinometer ATAGO PAL-06. Garam dalam larutan tersebut diukur sebagai konsentrasi kepekatan \%o.

\section{Preparasi Sampel}

Teripang pasir diambil seluruh tubuhnya \pm 500 gram, kemudian dicuci, diiris kecil-kecil, selanjutnya diblender.

\section{Ekstraksi Sampel}

Metode ekstraksi yang digunakan untuk mengekstrak teripang pasir menggunakan dua macam ekstraksi yaitu ekstraksi maserasi dilanjutkan dengan ekstraksi cair-cair. Langkah pertama, teripang pasir diekstraksi maserasi, teripang pasir ditimbang 150 gram, kemudian direndam dalam metanol : aquades (9:1) sebanyak $300 \mathrm{~mL}$ selama 24 jam dan dishakker selama 5 jam dengan kecepatan $150 \mathrm{rpm}$. Selanjutnya, ampas direndam kembali sampai filtrat yang didapat bening.Filtrat disaring dari ampasnya menggunakan vacum buchner, filtrat yang diperoleh digabungkan, kemudian dirotary evaporatordan diuapkan sisa pelarutnya menggunakangas $\mathrm{N}_{2}$. Selanjutnya ekstrak yang diperoleh dihitung rendemennya.

Ekstrak pekat yang diperoleh dilakukan pemisahan senyawa aktifnya berdasarkan kepolarannya menggunakan ekstraksi cair-cair, dengandua pelarut yang berbeda yaitu metanol dan $n$-heksana(1:1) 
sebanyak $150 \mathrm{~mL}$ masing-masing sebagai pelarut polar dan nonpolar. Filtrat yang diperoleh dirotary evaporator, kemudian ekstrak yang diperoleh diuapkan sisa pelarutnya menggunakan gas $\mathrm{N}_{2}$. Rendemen dari masing-masing ekstrakdihitung.

Ekstrak yang diperoleh dari proses ekstraksi diuji kapasitas antioksidan danfenolik totalnya untuk mengetahui ekstrak yang mengandung kapasitas antioksidan dan fenolik total tertinggi.

\section{Uji Antioksidan Menggunakan Metode DPPH}

\section{Penentuan Panjang Gelombang Maksimum}

Larutan DPPH 0,2 mM sebanyak 3 $\mathrm{mL}$, didiamkan \pm 10 menit. Larutan dicari $\lambda_{\text {maks }}$ nya dan dicatat hasil pengukuran $\lambda_{\text {maks }}$ untuk digunakan pada tahap selanjutnya (Rahayu, dkk, 2010).

\section{Penentuan Waktu Kestabilan \\ Pengukuran Antioksidan}

Larutan ekstrak 200 ppm diambil sebanyak 6,75 mL, ditambahkan sebanyak 2,25 mL larutan DPPH 0,2 mM, kemudian dicari waktu kestabilan tanpa inkubasi dan setelah inkubasi dengan interval 5 menit sampai waktu yang diperoleh stabil. Sampel diukur pada $\lambda_{\text {maks }}$ dan waktu kestabilan yang telah diperoleh.

\section{Pengukuran Kapasitas Antioksidan Pada Sampel}

Sampel ekstrak pekat metanol dan $n$ heksana masing-masing dilarutkan dalam pelarutnya dengan konsentrasi 1, 5, 10, 25, 50, 100, 200 dan 400 ppm. Kemudian tiaptiap konsentrasi diambil 2,25 $\mathrm{mL}$ dan ditambahkan DPPH 0,2 mM sebanyak 0,75 $\mathrm{mL}$ (larutan DPPH : Ekstrak yang dilarutkan dengan konsentrasi tertentu 1:3). Diinkubasi suhu $37^{\circ} \mathrm{C}$ pada waktu kestabilan yang didapatkan pada tahap sebelumnya, kemudian dimasukkan ke dalam kuvet untuk mengukur absorbansinya pada $\lambda_{\text {maks }}$ Data absorbansinya yang diperoleh dari tiap konsentrasi masing-masing ekstrak dihitung nilai \% kapasitas antioksidan.
Nilai tersebut diperoleh dengan rumus (Arindah, 2010) :

\% Kapasitas antioksidan $=\frac{A o-A c}{A o} \times 100 \%$

Keterangan :

$\mathrm{A}_{0}=$ Absorbansi kontrol

$\mathrm{A}_{\mathrm{c}}=$ Absorbansi sampel

Setelah didapatkan nilai \% kapasitas antioksidan sampel, selanjutnya dibandingkan kapasitasnya dengan pembanding (Vitamin C dan BHT).

Kontrol yang digunakan hanya larutan DPPH 0,2 mM tanpa penambahan sampel tetapi pembuatannya bersamaan dengan pembuatan sampel. Pembanding dibuat dengan cara yang sama tetapisampel diganti dengan asam askorbat (Vitamin C) dan BHT. Apabila \% kapasitas antioksidan sampel sama atau mendekati nilai kapasitas antioksidan pembanding maka dapat dikatakan bahwa sampel berpotensi sebagai salah satu alternatif antioksidan (Yuliani, 2010).

\section{Uji Kadar Fenolik Total}

\section{Penentuan Konsentrasi Standar dan Waktu Kestabilan Fenolik Total}

Asam galat dilarutkan dalam buffer fosfat dengan konsentrasi 0, 25, 50, 100, 200, 400, 600, 1000, 1200, 1400, 1600, 1800 dan 2000 ppm, kemudian dicari waktu kestabilan pengukuran fenolik pada rentangan 0-130 menit interval 10 menit. Sampel diukur pada panjang gelombang $655 \mathrm{~nm}$ menggunakan blanko buffer fosfat. Sampel diukur dengan dua alat yang berbeda yaitu menggunakan spektrofotometer UV-Vis Varian dan Spektrofotometer Elisa.

\section{Pembuatan Larutan Standar}

Asam galat dilarutkan dalam buffer fosfat dengan konsentrasi optimum, kemudian diinkubasi selama waktu optimum dari penentuan konsentrasi dan waktu kestabilan di atas. Standar diukur dengan panjang gelombang $655 \mathrm{~nm}$ menggunakan buffer fosfat sebagai blankonya. 


\section{Pengukuran Kadar Fenolik Total}

Kandungan total fenol diukur dengan uji Folin-Ciocalteu menggunakan asam galat sebagai standar. Sampel ekstrak kasar metanoldan $n$-heksana masing-masing dilarutkan dalam pelarutnya dengan konsentrasi 75, 150, 300, 600, 800, dan $1000 \mathrm{ppm}$. Ekstrak diambil $50 \mu \mathrm{L}$ dari tiap-tiap konsentrasi, ditambahkan aquades (3 mL), $250 \mu \mathrm{L}$ larutan Folin-Ciocalteu dan $7 \% \mathrm{NaCO}_{3}(750 \mu \mathrm{L})$ divortex dan diinkubasikan selama 8 menit pada suhu kamar. Langkah selanjutnya adalah penambahan $950 \mu \mathrm{L}$ aquades. Larutan didiamkan selama 80 menit pada suhu ruang. Diukur nilai absorbansi menggunakan panjang gelombang $655 \mathrm{~nm}$. Kandungan total fenol dinyatakan dengan ekuivalen asam galat (mg EAG/g sampel). Kandungan fenolik total yang tertinggi dan hasil uji reagen yang positif dilakukan pemisahan senyawa aktif dengan metode KLT (Kromatografi Lapis Tipis) menggunakan eluen terbaik.

\section{Uji Kandungan Senyawa Aktif dengan Uji Reagen}

$\begin{array}{rrr}\text { Ekstrak } & \text { teripang } & \text { pasir diuji } \\ \text { kandungan } & \text { senyawa } & \text { aktifnya }\end{array}$ menggunakan uji reagen (uji fitokimia) sehingga diketahui hasilnya secara kualitatif. Uji reagen diantaranya yaitu uji alkaloid, flavonoid, saponin dan triterpenoid/steroid (Indrayani dkk, 2006).

\section{Uji Alkaloid}

Ekstrak teripang pasir dimasukkan dalam tabung reaksi, ditambah $0,5 \mathrm{~mL} \mathrm{HCl}$ $2 \%$ dan larutan dibagi dalam dua tabung. Tabung I ditambahkan 2-3 tetes reagen Dragendorff, tabung II ditambahkan 2-3 tetes reagen Mayer. Jika tabung I terbentuk endapan jingga dan pada tabung II terbentuk endapan kekuning-kuningan, menunjukkan adanya alkaloid.

\section{Uji Flavonoid}

Ekstrak teripang pasir dimasukkan dalam tabung reaksi kemudian dilarutkan dalam 1-2 mL metanol panas 50\%. Setelah itu ditambah logam $\mathrm{Mg}$ dan 4-5 tetes $\mathrm{HCl}$ pekat. Larutan berwarna merah atau jingga yang terbentuk, menunjukkan adanya flavonoid.

\section{Uji Saponin}

Ekstrak teripang pasir dimasukkan dalam tabung reaksi ditambah air (1:1) sambil dikocok selama 1 menit, apabila menimbulkan busa ditambahkan $\mathrm{HCl} 1 \mathrm{~N}$, busa yang terbentuk dapat bertahan selama 10 menit dengan ketinggian $1-3 \mathrm{~cm}$, maka ekstrak positif mengandung saponin.

\section{Uji Triterpenoiddan Steroid}

Ekstrak teripang pasir dimasukkan dalam tabung reaksi, dilarutkan dalam 0,5 $\mathrm{mL}$ kloroform kemudian ditambah dengan $0,5 \mathrm{~mL}$ asam asetat anhidrat. Campuran ini selanjutnya ditambah dengan 1-2 mL $\mathrm{H}_{2} \mathrm{SO}_{4}$ pekat melalui dinding tabung tersebut. Jika hasil yang diperoleh berupa cincin kecoklatan atau violet pada perbatasan dua pelarut menunjukkan adanya triterpenoid, sedangkan jika terbentuk warna hijau kebiruan menunjukkan adanya steroid.

\section{Pemisahan Kandungan Senyawa Aktif Menggunakan KLT}

Identifikasi dengan KLT menggunakan plat silika gel $\mathrm{F}_{254}$ sebagai fase diamnya. Masing-masing plat disiapkan dengan ukuran $1 \times 10 \mathrm{~cm}$ setelah diaktivasi selama \pm 15 menit dalam oven suhu $100{ }^{\circ} \mathrm{C}$. Ekstrak teripang pasir ditotolkan pada jarak $\pm 1 \mathrm{~cm}$ dari tepi bawah plat dengan pipa kapiler, kemudian dikeringkan plat silika gel dan ditotolkan kembali ekstrak teripang pasir dengan menggunakan pipa kapiler sebanyak $1 \mathrm{~mL}$. Perlakuan ini dihentikan sampai dirasa sudah cukup.Kemudian hasil penotolan akan dielusi dengan menggunakan eluen atau fase gerak seperti yang ditunjukkan pada lampiran 1. Setelah gerakan fase gerak sampai pada garis batas, elusi dapat dihentikan.

Noda-noda pada permukaan plat diperiksa di bawah sinar UV pada panjang gelombang $254 \mathrm{~nm}$ dan $366 \mathrm{~nm}$, kemudian diamati masing-masing hasil nodanya. Bercak noda yang dihasilkan pada masing- 
masing plat KLT selanjutnya dihitung nilai Rf-nya.

\section{HASIL DAN PEMBAHASAN Analisis Kadar Air}

Hasil uji kadar air teripang pasir diperoleh sebesar 79,97 \%. Uji kadar air ini dilakukan untuk acuan penambahan pelarut yang digunakan dalam ekstraksi maserasi. Tingginya kadar air pada sampel $(79,97 \%)$ menyebabkan daya simpan sampel menjadi rendah. Jika sampel segar disimpan dalam waktu lama kemungkinan sampel akan ditumbuhi jamur atau mikroba yang dapat berpengaruh terhadap senyawa aktif dari sampel.

\section{Analisis Kadar Garam}

Hasil pengukuran kadar garam teripang pasir diperoleh sebesar $15,45 \%$. Tujuan dari uji kadar garam ini sebagai informasi tambahan untuk pengaruh hasil rendemen yang diperoleh.

\section{Preparasi Sampel}

Sampel yang digunakan dalam penelitian ini adalah teripang pasir (Holothuria scabra) masih segar yang diperoleh dari Pantai Kenjeran Surabaya.Sampel teripang pasir dicuci sampai bersih kemudian dihaluskan dengan blender bertujuan untuk memperluas permukaan sampel agar memudahkan kontak antara pelarut dengan sampel pada saat ekstraksi maserasi.

\section{Ekstraksi Sampel}

Ekstraksi yang digunakan pada penelitian ini untuk mengekstrak teripang pasir menggunakan ekstraksi maserasi dan dilanjutkan dengan ekstraksi partisi (ekstraksi cair-cair).

Rendemen hasil ekstraksi pada penelitian ini masing-masing yaitu metanol $(11,28 \%)$ dan $n$-heksana $(1,38 \%)$.

\section{Uji Antioksidan Menggunakan Metode} DPPH (1,1-difenil-2-pikrilhidrasil)
Langkah awal yang dilakukan dalam pengujian dengan metode DPPH yaitu menentukan panjang gelombang maksimum dari DPPH menggunakan spektrofotometer UV-Vis. Hasil penentuan panjang gelombang DPPH $0,2 \mathrm{mM}$ diperoleh panjang gelombang maksimum sebesar $515 \mathrm{~nm}$. Hasil spektra UV-Vis larutan DPPH adalah sebagai berikut :

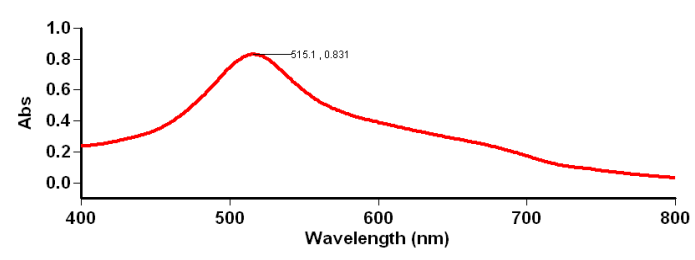

Gambar 1 Spektra UV-Vis larutan DPPH dalam etanol

\section{Penentuan Waktu Kestabilan Pengukuran Antioksidan}

Penentuan waktu kestabilan ini bertujuan untuk mengetahui waktu kestabilan reaksi antara DPPH dengan sampel antioksidan yang digunakan. Pengukuran waktu kestabilan ini dilakukan dengan dua cara, yaitu larutan diinkubasi pada suhu ruang $\left(25-27^{\circ} \mathrm{C}\right)$ dan larutan diinkubasi pada suhu $37^{\circ} \mathrm{C}$ dilakukan sampai larutan stabil dengan interval 5 menit. Hasil penentuan waktu kestabilan dapat dilihat pada tabel 1 .

Tabel 1Hasil Penentuan Waktu Kestabilan Pengkuran Antioksidan

\begin{tabular}{lcc}
\multirow{2}{*}{ Sampel } & \multicolumn{2}{c}{$\begin{array}{c}\text { Waktu Kestabilan } \\
\text { (menit) }\end{array}$} \\
\cline { 2 - 3 } & $\begin{array}{c}\text { Inkubasi } \\
\text { pada Suhu } \\
\mathbf{3 7} 7^{\circ} \mathbf{C}\end{array}$ & $\begin{array}{c}\text { Inkubasi } \\
\text { pada } \\
\text { Suhu 25 } \\
\mathbf{2 7} \mathbf{\circ}^{\circ} \mathbf{C}\end{array}$ \\
\hline $\begin{array}{l}\text { Fraksi } \\
\text { metanol }\end{array}$ & $25-70$ & $30-45$ \\
\hline $\begin{array}{l}\text { Fraksi } n- \\
\text { heksana }\end{array}$ & $80-100$ & $85-90$ \\
\hline $\begin{array}{l}\text { Vitamin } \\
\text { C }\end{array}$ & $20-50$ & $25-35$ \\
\hline BHT & $80-120$ & $85-100$ \\
\hline
\end{tabular}

Berdasarkan Tabel 1 dapat dijelaskan bahwa pengujian antioksidan sangat baik jika menggunakan inkubasi pada suhu 
$37^{\circ} \mathrm{C}$, karena cenderung menghasilkan absorbansi yang tidak jauh berbeda dan lama.Berbeda dengan absorbansi sampel pada suhu ruang $\left(25-27^{\circ} \mathrm{C}\right)$ yang cenderung berubah dan kurang stabil pada rentang waktu yang berbeda. Diduga suhu yang telah terkondisikan dapat mempercepat berlangsungnya reaksi antara radikal DPPH dan senyawa antioksidan.

\section{Pengukuran Kapasitas Antioksidan Sampel dengan Metode DPPH}

Data \% kapasitas antioksidan ekstrak teripang pasir serta pembanding BHT dan asam askorbat ditunjukkan pada Tabel 2.

Tabel 2 Hasil pengukuran \% kapasitas antioksidan ekstrak teripang pasir

\begin{tabular}{lcccc}
\hline $\begin{array}{c}\text { Konsejntrasi } \\
\begin{array}{c}\text { Sampel } \\
\text { (ppm) }\end{array}\end{array}$ & $\begin{array}{c}\text { Ekstrak } \\
\text { metanol }\end{array}$ & $\begin{array}{c}\text { Ekstrak } \\
\boldsymbol{n} \text {-heksana }\end{array}$ & BHT & $\begin{array}{c}\text { Asam } \\
\text { askorbat }\end{array}$ \\
\hline 1 & 76,61 & 94,82 & 76,04 & 80,10 \\
\hline 5 & 77,07 & 94,51 & 76,65 & 90,45 \\
\hline 10 & 77,24 & 94,68 & 81,47 & 98,92 \\
\hline 25 & 76,82 & 94,33 & 85,71 & 99,21 \\
\hline 50 & 78,02 & 94,01 & 93,73 & 99,22 \\
\hline 100 & 78,33 & 93,63 & 95,87 & 99,23 \\
\hline 200 & 78,83 & 90,46 & 98,87 & 99,24 \\
\hline 400 & 79,82 & 75,20 & 99,09 & 99,26 \\
\hline
\end{tabular}

Berdasarkan data pada Tabel 2 dapat diketahui bahwa ekstrak metanol mempunyai aktivitas antioksidan yang sedang, ha1 ini ditunjukkan dengan kemampuan ekstrak methanol dalam menghambat perkembangan radikal bebas sebesar 79,82\%. Sedangkan ekstrak $n$ heksana mempunyai aktivitas sangat kuat, karena mampu menghambat radikal bebas sebesar 94,82\%. Ekstrak n-heksana memiliki kapasitas antioksidan yang berbanding terbalik dengan ekstrak metanol, yaitu dari konsentrasi rendah ketinggi semakin kecil. Perbedaan ini diduga karena ekstrak yang digunakan masih berupa ekstrak kasar, sehingga senyawa yang terkandung di dalam ekstrak kasar sampel fraksi metanol maupunnheksana diduga masih mengandung gugusgugus lain yang dapat mempengaruhi pengukuran antioksidan maupun prooksidan.
Hasil \% kapasitas antioksidan sampel (ekstrak fraksi metanol dan $n$-heksana) dapat dibandingkan dengan pembanding (BHT dan Vitamin C) menggunakan persamaan regresi linear. Hasil \% kapasitas antioksidan dari masing - masing ekstrak dapat dilihat pada lampiran 6. Hasil dari perbandingan $\%$ kapasitas antioksidan sampel dengan pembanding yang memiliki nilai terbaik dapat dilihat pada Tabel 3 .

Tabel 3 Hasil perbandingan \% kapasitas antioksidan sampel dengan pembanding

\begin{tabular}{lcccc}
\hline Sampel & $\begin{array}{c}\text { Konsentrasi } \\
\text { (ppm) }\end{array}$ & $\begin{array}{c}\text { \% Kapasitas } \\
\text { Antioksidan } \\
\text { Sampel }\end{array}$ & $\begin{array}{c}\text { Setara dengan } \\
\text { \% Kapasitas } \\
\text { Antioksidan } \\
\text { BHT }\end{array}$ & $\begin{array}{c}\text { Setara dengan } \\
\text { \% Kapasitas } \\
\text { Antioksidan } \\
\text { Vit. C }\end{array}$ \\
\hline $\begin{array}{l}\text { Ekstrak } \\
\text { fraksi } \\
\text { metanol }\end{array}$ & 400 & 79,82 & 10,17 & $<1$ \\
\hline $\begin{array}{l}\text { Ekstrak } \\
\text { fraksi } n- \\
\text { heksana }\end{array}$ & 1 & 94,82 & $>50$ & 7,75 \\
\hline
\end{tabular}

Berdasarkan data Tabel 3 yang diperoleh menunjukkan bahwa ekstrak fraksi $n$-heksana memiliki nilai \% kapasitas antioksidan tertinggi dibandingkan dengan ekstrak fraksi metanol. Hal ini dapat dilihat bahwa ekstrak fraksi $n$-heksana dengan konsentrasi 1 ppm mampu menghasilkan $\%$ kapasitas antioksidan tinggi dibandingkan dengan ekstrak fraksi metanol.

Ekstrak fraksi $n$-heksana dengan konsentrasi 1 ppm mampu menghasilkan \% kapasitas antioskidan sebesar 94,82\% setara dengan $>50 \%$ kapasitas antioksidan BHT dan 7,75\% kapasitas antioksidan Vit. $\mathrm{C}$,sedangkan ekstrak fraksi metanol dengan konsentrasi 400 ppm menghasilkan \% kapasitas antioksidan sebesar 79,82\% setara dengan $10,17 \%$ kapasitas antioksidan BHT dan $<1 \%$ Kapasitas antioksidan Vitamin C.

\section{Pengukuran Kadar Fenolik Total}

Kandungan senyawa fenolik pada ekstrak teripang pasir diukur dengan menggunakan reagen Folin-Ciocalteu pada panjang gelombang $655 \mathrm{~nm}$. 
Hasil pengujian fenolik total dari ekstrak teripang pasir dari masing-masing fraksi yaitu metanol $(69,09 \mathrm{EAG} / \mathrm{g}$ sampel) dan $n$-heksana (58,01 EAG/g sampel).

\section{Uji Kandungan Senyawa Aktif Menggunakan Uji Reagen}

Hasil uji reagen ekstrak teripang pasir ditunjukkan pada Tabel 4.

Tabel 4 Hasil uji reagen ekstrak teripang pasir

\begin{tabular}{l|c|c}
\hline \multicolumn{1}{c|}{ Uji Reagen } & $\begin{array}{c}\text { Fraksi } \\
\text { metanol }\end{array}$ & $\begin{array}{c}\text { Fraksi } \\
\boldsymbol{n} \text {-heksana }\end{array}$ \\
\hline Saponin & - & + \\
\hline Triterpenoid & + & - \\
\hline Steroid & - & - \\
\hline Alkaloid: & & - \\
- R. Mayer & - & - \\
- R. & - & \\
Dragendroff & & - \\
\hline Flavonoid & - & \\
\hline
\end{tabular}

Pemisahan Senyawa Aktif pada Ekstrak Teripang Pasir Menggunakan KLT

Pemisahan senyawa aktif dengan KLT ini bertujuan untuk mencari eluen terbaik dari beberapa eluen yang baik dalam pemisahan senyawa triterpenoid. Eluen yang baik adalah eluen yang dapat memisahkan senyawa dalam jumlah yang banyak ditandai dengan munculnya banyak spot.

Hasil dari data spot KLT analitik ekstrak teripang pasir fraksi metanol dapat dilihat di Tabel 5. Diantara keseluruhan campuran eluen terdapat 5 eluen yang menghasilkan pemisahan spot yang baik yaitu eluen metanol : kloroform (5:2), metanol : kloroform (1:2), metanol : kloroform (7:3), $n$-butanol : $\mathrm{NH}_{4} \mathrm{OH}$ (4:1) dan kloroform : metanol : aquades (20:60:4). Hasil KLT analitik dapat dilihat pada Tabel 5.

Spot hasil KLT menggunakan eluen n-butanol : $\mathrm{NH}_{4} \mathrm{OH}$ (4:1) menghasilkan spot lebih baik, karena spot yang dihasilkan tidak berekor dan menghasilkan spot yang lebih banyak.
Hasil KLT analitik $n$-butanol : $\mathrm{NH}_{4} \mathrm{OH}$ (4:1) disajikan dalam Gambar 3 dan Tabel 6.

Tabel 5 Hasil KLT dengan masing-masing eluen

\begin{tabular}{|c|c|c|}
\hline Jenis Eluen & $\begin{array}{c}\text { Nilai Rf spot } \\
\text { yang dihasilkan }\end{array}$ & $\begin{array}{l}\text { Warna spot di bawah sinar UV } \\
\lambda .366 \mathrm{~nm} \text { setelah disemprot LB }\end{array}$ \\
\hline $\begin{array}{l}\text { Metanol:kloroform } \\
(5: 2)\end{array}$ & 0,$19 ; 0,68$ & $\begin{array}{l}\text { Merah keunguan, } \\
\text { kehijauan }\end{array}$ \\
\hline $\begin{array}{l}\text { Metanol:kloroform } \\
(1: 2)\end{array}$ & 0,$64 ; 0,78$ & Kuning kehijuan, biru \\
\hline $\begin{array}{l}\text { Metanol:kloroform } \\
(7: 3)\end{array}$ & 0,$20 ; 0,70$ & $\begin{array}{l}\text { Merah keunguan, } \\
\text { kehijauan }\end{array}$ \\
\hline $\begin{array}{l}n \text {-butanol: } \mathrm{NH}_{4} \mathrm{OH} \\
(4: 1)\end{array}$ & $\begin{array}{l}0,10 ; 0,16 ; 0,30 ; \\
0,45\end{array}$ & Biru, biru, biru, biru kemerahan \\
\hline $\begin{array}{l}\text { kloroformmetanol } \\
\text { :air }(20: 60: 4)\end{array}$ & 0,$67 ; 0,75$ & Putih kekuningan, biru keunguan \\
\hline
\end{tabular}

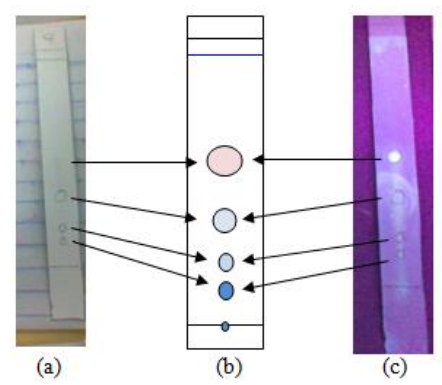

Gambar 3 Profil plat hasil KLT ekstrak teripang pasir fraksi metanol eluen $n$-butanol : $\mathrm{NH}_{4} \mathrm{OH}(4: 1)$.

Keterangan:

(a) hasil elusi setelah disemprot reagen LiebermanBurchard

(b) gambar hasil pengamatan

(c) hasil pengamatan sinar UV pada $\lambda 366 \mathrm{~nm}$ setelah disemprot reagen Lieberman-Burchard.

Tabel 6 Hasil KLT ekstrak teripang pasir fraksi metanol denganeluen $n$ butanol : $\mathrm{NH}_{4} \mathrm{OH}(4: 1)$

\begin{tabular}{|c|c|c|c|c|c|}
\hline \multirow[b]{2}{*}{$\begin{array}{c}\text { Rf } \\
\text { tiap } \\
\text { noda }\end{array}$} & \multicolumn{2}{|c|}{$\begin{array}{c}\text { Warna noda tanpa sinar } \\
\text { UV pada } \lambda .366 \mathrm{~nm}\end{array}$} & \multicolumn{2}{|c|}{$\begin{array}{l}\text { Warna noda di bawah } \\
\text { sinar UVpada } \lambda .366 \mathrm{~nm}\end{array}$} & \multirow[b]{2}{*}{$\begin{array}{c}\text { Dugaan } \\
\text { Senyawa yang } \\
\text { Mungkin }\end{array}$} \\
\hline & \begin{tabular}{|c|} 
sebelum \\
disemprot \\
reagen \\
Lieberman- \\
Burchard \\
\end{tabular} & \begin{tabular}{|c|} 
setelah \\
disemprot \\
reagen \\
Lieberman- \\
Burchard \\
\end{tabular} & \begin{tabular}{|c|} 
sebelum \\
disemprot \\
reagen \\
Lieberman- \\
Burchard \\
\end{tabular} & \begin{tabular}{|c|} 
setelah \\
disemprot \\
reagen \\
Lieberman- \\
Burchard \\
\end{tabular} & \\
\hline 0,1 & $\begin{array}{c}\text { Tidak } \\
\text { berwama }\end{array}$ & $\begin{array}{c}\text { Tidak } \\
\text { berwama }\end{array}$ & Biru & Biru & Triterpenoid \\
\hline 0,16 & $\begin{array}{c}\text { Tidak } \\
\text { berwama }\end{array}$ & $\begin{array}{c}\text { Tidak } \\
\text { berwama }\end{array}$ & Kuning & Biru & Triterpenoid \\
\hline 0,3 & $\begin{array}{c}\text { Tidak } \\
\text { berwama }\end{array}$ & $\begin{array}{c}\text { Tidak } \\
\text { berwama }\end{array}$ & Biru & Biru & Triterpenoid \\
\hline 0,45 & $\begin{array}{c}\text { Tidak } \\
\text { berwama }\end{array}$ & $\begin{array}{c}\text { Merah } \\
\text { keunguan }\end{array}$ & $\begin{array}{c}\text { Tidak } \\
\text { berwama }\end{array}$ & $\begin{array}{c}\text { Biru } \\
\text { kemerahan }\end{array}$ & Triterpenoid \\
\hline
\end{tabular}

Golongan senyawa triterpenoid hasil KLT setelah desemprot dengan reagen Lieberman-Burchard ditunjukkan dengan terbentuknya bercak noda berwarna hijau 
kebiruan (Handayani, 2008) hijau tua sampai ungu tua (Bawa, 2009), merah kecoklatan sampai merah ungu (Halimah, 2010). Spot-spot hasil KLT pada ekstrak teripang pasir fraksi metanol ini diduga merupakan golongan senyawa triterpenoid.

\section{KESIMPULAN DAN SARAN}

\section{Kesimpulan}

Hasil penelitian yang telah dilakukan dapat disimpulkan bahwa sebagai berikut :

1. Kandungan fenolik total pada teripang pasir (Holothuria scabra) fraksi metanol sebesar 69,09 mg EAG/gr sampel, sedangkan pada fraksi nheksana sebesar 58,01 mg EAG/gr sampel.

2. Kapasitas antioksidan pada teripang pasir fraksi metanol sebesar 79,82 \%, sedangkan pada fraksi $n$-heksana sebesar $94,82 \%$.

3. Hasil uji reagen pada fraksi metanolekstrak teripang pasir menunjukkan adanya golongan senyawa triterpenoid, sedangkan pada fraksi $n$-heksana menunjukkan adanya golongan senyawa saponin.

4. Eluen yang terbaik untuk memisahkansenyawa aktif ekstrak teripang pasir fraksi metanol menggunakan metode KLT yaitu $n$ butanol : $\mathrm{NH}_{4} \mathrm{OH}(4: 1)$.

\section{Saran}

Penelitian ini agar mendekati sempurna saran yang perlu diperbaiki dari penelitian ini, diantaranya yaitu:

1. Diperlukan penelitian lebih lanjut sampai pada tahap identifikasi agar dapat mengetahui senyawa yang berpotensi sebagai antioksidan tersebut.

\section{DAFTAR PUSTAKA}

Bawa, I. G. A. G. 2009. Isolasi dan Identifikasi Golongan Senyawa Toksik dari Daging Buah Pare (Momordica charantia L.). Bukit Jimbaran: Jurusan Kimia FMIPA Universitas Udayana. Jurnal
Kimia 3(2). ISSN 1907-9850: 1117-124.

Halimah, N. 2010. Uji Fitokimia dan Uji Toksisitas Ekstrak Tanaman Anting-Anting (Acalypha indica L.) Terhadap Larva Udang Artemia salina Leach. Skripsi Tidak Diterbitkan. Malang: Jurusan Kimia Fakultas Sains dan Teknologi Universitas Islam Negeri Maulana Malik Ibrahim Malang.

Kadin. 2004. NKRI: Negara Kepulauan Republik Indonesia. http://www.kadinbatam.or.id/imu/t mi.pdf. diakses pada tanggal 05 Oktober 2011.

Nurhidayati. 2009. Efek Protektif Teripang Pasir (Holothuria scabra) terhadap Hepatotoksistas yang Diinduksi Karbon Tetraklorida $\left(\mathrm{CCl}_{4}\right)$. Surabaya: Universitas Airlangga.

Sateni. 2012. Wawancara Pribadi dilakukan pada tanggal 16 September 2012. Surabaya.

Yuliani, D. 2010. Kajian Aktivitas Antioksidan Fraksi Etanol Jinten Hitam (Nigella sativa, L.). Malang: Jurusan Kimia UIN MALIKI Malang. 